\title{
Lutropin alpha, recombinant human luteinizing hormone, for the stimulation of follicular development in profoundly LH-deficient
} hypogonadotropic hypogonadal women: a review

This article was published in the following Dove Press journal: Biologics:Targets \& Therapy

18 June 2009

Number of times this article has been viewed

\author{
Bernd Th Krause' \\ Ralf Ohlinger ${ }^{2}$ \\ Annette Haase ${ }^{3}$ \\ 'Center for Endocrinology \\ and Reproductive Medicine, \\ MVZ Uhlandstr, Berlin, Germany; \\ ${ }^{2}$ Ernst-Moritz-Arndt-University, \\ Department of Gynecology and \\ Obstetrics, Greifswald, Germany; \\ ${ }^{3}$ Uhlandstr. 162, 10719 Berlin
}

Correspondence: Bernd Th Krause MVZ Uhlandstr. 19, 10623

Berlin, Germany

Tel +493088716363

$\mathrm{Fax}+4930887163659$

Email bthkrause@web.de

\begin{abstract}
Hypogonadotropic hypogonadism is defined as a medical condition with low or undetectable gonadotropin secretion, associated with a complete arrest of follicular growth and very low estradiol. The main cause can be traced back to an irregular or absent hypothalamic GnRH secretion, whereas only a minority suffers from a pituitary disorder. The choice of treatment to reverse this situation is a pulsatile GnRH application or a direct ovarian stimulation using gonadotropin injections. The goal is to achieve a proper ovarian function in these cases for a short time to allow ovulation and chance of pregnancy. Since the pulsatile GnRH treatment lost its former importance, several gonadotropins are in use to stimulate follicular growth, such as urine-derived human menopausal gonadotropin, highly purified follicle stimulating hormone (FSH) or recombinant FSH, all with different success. The introduction of recombinant luteinizing hormone ( $\mathrm{LH})$ and FSH provided an opportunity to investigate the distinct influences of LH and FSH alone and in combination on follicular growth in monofollicular ovulation induction cycles, and additionally on oocyte maturation, fertilization competence of the oocyte and embryo quality in downregulated IVF patients. Whereas FSH was known to be indispensable for normal follicular growth, the role of LH remained questionable. Downregulated IVF patients with this short-term gonadotropin depletion displayed no advance in stimulation success with the use of recombinant LH. Patients with hypogonadotropic hypogonadism undergoing monofollicular stimulation for ovulation induction showed clearly a specific role and need for both hormones in normal follicular growth. Therefore, a combined stimulation with FSH and LH seems to be the best treatment choice. In the first half of the stimulation cycle the FSH dosage should exceed that of LH by 2:1, with an inverse ratio for the second half.
\end{abstract}

Keywords: hypogonadotropic hypogonadism, ovarian stimulation, ovulation induction, recombinant luteinizing hormone

\section{Introduction}

Hypogonadotropic hypogonadism $(\mathrm{HH})$ is a rare disease, characterized by low or undetectable levels of luteinizing hormone ( $\mathrm{LH})$ and follicle stimulating hormone (FSH) and a chronic estradiol deficiency, due to a complete arrest of follicular growth with subsequent amenorrhea. The low or undetectable gonadotropins portray the common endpoint of different diseases and circumstances. Despite a few cases of pituitary origin such as adenomas or inflammation (hypophysitis), the majority of $\mathrm{HH}$ patients suffer from a disturbed hypothalamic gonadotropin-releasing hormone $(\mathrm{GnRH})$ secretion. ${ }^{1,2}$ The irregular GnRH secretion can be traced back to a morphological 
correlate such as Kallmann's syndrome, adrenal hypoplasia congenita (in men), GnRH gene mutation or Leptin gene mutation in just $10 \%$ of all cases. ${ }^{3,4}$ The remaining $90 \%$ can be subsumed as a functional disturbance of pulsatile GnRH secretion, caused by eating disorders, emotional stress or excessive exercise (long distance runners). In the latter, diagnosis can only be made by exclusion of other abnormalities. $^{5}$

Regardless of the origin and underlying cause, $\mathrm{HH}$ also means profound infertility. Therefore, many attempts had been made to override the arrest of follicular growth and achieve a regular ovulatory function of these ovaries. From pulsatile GnRH application as the most physiological treatment to daily injections of different gonadotropins with different stimulation protocols have all been done to achieve normal follicular growth and chance of pregnancy. $\mathrm{HH}$ women with their long lasting gonadotropin depletion represent a very distinct group of patients in reproductive medicine. In this review, we will describe and discuss the influence of LH and FSH on normal follicular growth and the results of different stimulation protocols in the treatment of $\mathrm{HH}$ women to achieve monofollicular growth for ovulation induction, with special attention on the effect of LH. Additionally, several studies dealing with IVF patients as a model for $\mathrm{HH}$ women will be discussed to prove the influence of LH on oocyte quality, fertilization competence and embryo quality.

\section{GnRH secretory patterns and follicular growth}

GnRH, a 10 amino acid peptide, will be produced (mainly) by hypothalamic neurons to stimulate the gonadotropic cells in the pituitary.

The hypothalamic-pituitary-gonadal axis is driven by a neuronal pacemaker, located in the mediobasal hypothalamus, on the bottom of the third ventricle. Approximately 15,000 neurons release $\mathrm{GnRH}$ in a pulsatile fashion from the eminentia mediana into the portal vein system. ${ }^{6}$

GnRH stimulates the production of $\mathrm{LH}$ and FSH in the pituitary and the pulsatile release of $\mathrm{LH}$, and in part of $\mathrm{FSH},{ }^{7,8}$ whereas GnRH pulsatility influences FSH bioactivity more than its secretion. ${ }^{7}$ Several neurotransmitters such as GABA, ${ }^{9}$ endogenous opioids, ${ }^{10}$ neuropeptide $\mathrm{Y},{ }^{11}$ galanin ${ }^{12}$ or norepinephrine ${ }^{13}$ are involved in the regulation of pulsatile GnRH secretion.

Even slight changes in GnRH pulse frequency disturb fundamentally LH and FSH secretion and also their bioactivity. ${ }^{2,14}$ Normal follicular growth will slow down until a complete arrest of follicular growth. Menstrual irregularities, anovulation or oligomenorrhea are the external signs of this malfunction. In the more severe cases, this will lead to a complete ovarian failure and subsequent lost of menstrual bleeding, a central or hypothalamic amenorrhea.

Despite the irregular GnRH secretory patterns, the pituitary LH- and FSH-producing cells remain fullly sensitive to (external) normal GnRH secretion, at least for a while. This is one concept in the treatment of HH. ${ }^{15-17}$

\section{Ovarian physiology related to LH and FSH secretion Maturation of the follicles}

Follicular development from the primordial to the preovulatory stage occurs continuously in a random fashion and takes several months from the very early primordial follicles (primary or initial recruitment) until one follicle reaches the preovulatory stage. ${ }^{18}$ In this way, most of the developing follicles became atretic by apoptosis.

The early stages of follicular growth are independent from FSH. From the primary follicle onward, FSH receptors can be found, ${ }^{19}$ assuming a FSH dependency from this stage. Ovaries from HH women (Kallmann's syndrome) showed only a few follicles that had passed the primordial stage. ${ }^{20}$ Otherwise, as recently shown, follicular growth can still progress further in the absence of FSH until the antral stage. ${ }^{21}$

\section{Follicular phase characteristics}

At the end of the luteal phase, with demise of the corpus luteum, estradiol, progesterone and inhibin A decline. The falling progesterone level compromises the hypothalamic endogenous opioid tone, which will enable the GnRHproducing neurons to enhance their firing rate. .,22,23 $^{2}$

The subsequent increase in GnRH pulse frequency enhances pituitary FSH and LH production, ${ }^{7,24}$ and in face of a diminished inhibin $\mathrm{A},{ }^{25}$ the FSH level rises sharply to pass the threshold level for the secondary (or cyclic) recruitment of the next follicle cohort. ${ }^{26}$ Due to the FSH increase, this follicle cohort escapes apoptosis and continues to grow.

At this time LH stimulates follicular theca cells to produce androgens (androstendione). These androgens are required for estrogen synthesis by FSH-driven granulosa cells: ${ }^{27}$ the concept of the classic two cell-two gonadotropin model.

Additionally, FSH has been found to be necessary for normal androgen production, ${ }^{21}$ and an androgen-promoted stimulation of granulosa cell aromatase activity in antral follicles has been described, ${ }^{28}$ an LH arbitrated process. 
Throughout the follicular phase and with rising estradiol and inhibin levels the amount of circulating FSH declines continuously, whereas LH levels begin to climb ${ }^{29}$ and end in the preovulatory LH surge, with resumption of meiosis as the most significant LH function. ${ }^{30}$

Around the midfollicular stage, the increasing GnRH pulse frequency favors LH secretion. This higher GnRH pulse frequency also increases the bioactivity of secreted LH isoformes and decreases their half-life, resulting in an attenuated $\mathrm{LH}$ pulse amplitude in face of a higher LH pulse frequency. ${ }^{14,31}$ The resulting higher LH action drives the androgen output by the theca cells. ${ }^{32}$ These enhanced intrafollicular androgen levels acquire an amplified granulosa cell activity to avoid a massive intrafollicular accumulation of androgens, because this high androgenetic milieu promotes follicular atresia. ${ }^{33}$ Nevertheless, the intrafollicular androgens (at normal level) can improve the follicular development and oocyte quality. ${ }^{34}$

With the declining FSH, a much higher sensitivity to the remaining FSH will be needed to sustain sufficient granulosa cell activity. Additionally, with the rising estradiol level along the follicular phase, FSH changes its isoform to one of higher bioactivity, ${ }^{35}$ to compensate partly for the declining amount of FSH secreted.

\section{The dominant follicle}

Among the cohort of about 10 recruited follicles, normally only one follicle will arrive at the preovulatory stage with the ability to ovulate. This follicle grows faster and produces more estradiol, which is needed to inhibit the androgenetic driven apoptosis in the follicle,${ }^{36}$ and inhibin than the others. ${ }^{18}$ Within this cohort only the dominant follicle reaches the capability to continue to develop in face of diminishing $\mathrm{FSH}^{37}$

The leading position of the dominant follicle results from a higher sensitivity to FSH, due to a higher amount of FSH (and LH?) receptors or may be greater influenced by local (intrafollicular) growth factors, as these could act independently from FSH or just augment the FSH responsiveness. $^{18}$

Since FSH has been recognized as a conditio sine qua non for normal oocyte development, ${ }^{38}$ in the past LH was conceded only a minor role in follicle maturation.

According to the two cells -2 gonadotropins model mentioned above, the $\mathrm{LH}$ action was restricted to the stimulation of follicular theca cells to produce androgens as a precursor of estradiol. These androgens in turn traverse the follicular basement membrane for aromatization by FSH-driven granulosa cells. ${ }^{27}$
Each cell type has one specific receptor type and interacts only with LH or FSH.

With the midfollicular stage, when a follicle reaches 10 to $14 \mathrm{~mm}$ in diameter, granulosa cells increasingly express LH receptors ${ }^{39,40}$ until the late follicular phase, ${ }^{41}$ indicating a role for LH in final follicular development and oocyte maturation..$^{39}$ The $\mathrm{LH}$ receptor gene expression is mediated by $\mathrm{FSH}^{42,43}$ and may be facilitated by estradiol. ${ }^{44}$

With the inhibin-induced decreasing FSH levels at this time, ${ }^{45} \mathrm{LH}$ seems to sensitize the dominant follicle for the remaining low FSH and allows further growth. ${ }^{39}$ But in fact LH just takes over some of the action of the vanishing $\mathrm{FSH}^{46}$

Beside this, the rising LH levels lead also to an arrest of midsized follicles to secure monofollicular development and avoid multiple ovulations. ${ }^{47,48}$

Intraovarian modulators such as insulin growth factor(IGF-1), epidermal growth factor and tumor necrosis factor are also involved in the regulation of follicular growth by influencing theca and granulosa cell activity. ${ }^{26}$

In the past, the sensitizing of the dominant follicle to FSH was attributed to a higher amount of FSH receptors in the dominant follicle to allow more binding of the remaining few FSH molecules than the other less developed follicles. But with the existence of LH receptors on granulosa cells, this theory needs to be revised.

Obviously, from the midfollicular stage, LH partly takes over FSH action on granulosa cells. This could explain why the maturing dominant follicle becomes more independent from $\mathrm{FSH}^{49}{ }^{49}$ Interestingly, LH stimulates steroid genesis in mature granulosa cells, but inhibits further cell proliferation. Both the FSH-driven cell proliferation and the LH-induced inhibition are mediated by IGF- $1 .{ }^{50}$

These results demonstrate an inverse relationship between proliferation and steroid synthesis of granulosa cells as they differentiate.

The rising LH level enhances the androgen biosynthesis by theca cells, and in the face of a declining aromatase activity in the smaller, LH-receptor-free follicles, the high intrafollicular androgenetic milieu in these follicles will promote a follicular atresia. ${ }^{46}$ Thus, the LH receptor gene expression on granulosa cells is necessary to avoid follicular apoptosis and therefore represents one basic factor in the selection of the dominant follicle.

The expression of $\mathrm{LH}$ receptors on maturing granulosa cells in concert with climbing LH levels depict the key factors for the selection of the dominant follicle, to keep this follicle alive in face of diminished $\mathrm{FSH}^{33}$ and to avoid additional 
follicular growth with subsequent multiple ovulations by an enhanced apoptosis rate in midsized follicles. ${ }^{51}$

Once the follicular size has reached $14 \mathrm{~mm}$ in diameter, LH stimulation without FSH becomes able to continue further follicular growth. ${ }^{42,52}$

After the FSH-triggered secondary recruitment of the follicle cohort, a critical amount of LH and FSH will be necessary to maintain follicular growth and oocyte maturation. ${ }^{53}$ Additionally, the ability of the preovulatory follicles to transfer their gonadotropic dependence from FSH to LH seems to be absolutely crucial for follicle selection. ${ }^{54}$

Both hormones exert very different effects on granulosa cell gene expression ${ }^{55}$ or the extent of granulosa cell steroidogenesis prior to and after ovulation. ${ }^{56}$

The picture completely differs in men, where LH acts only on Leydig cells and FSH only on Sertoli cells without any cross action. ${ }^{57}$

\section{LH pharmacology}

LH shares an identical alpha-subunit with other hormones as part of a family of heterodimeric proteohormones (thyroidstimulating hormone, human chorionic gonadotrophin [HCG], FSH). The hormone unique beta-subunit confers the biological action and the ability to bind to a specific receptor. Both subunits are associated with noncovalent bonds. ${ }^{58,59}$

Until the end of the previous century, human menopausal gonadotropin (HMG) was the only commercially available source of LH activity. This preparation contains LH and FSH, derived from the urine of postmenopausal women. Due to an unstable proportion of $\mathrm{LH}$ and a reduced LH bioactivity in comparison to normal cycling women, ${ }^{31,60} \mathrm{HCG}$ was added as a LH substitute to allocate a 1:1 ratio of LH and FSH action, ${ }^{61}$ which means that HMG preparations contain different amounts of HCG. The LH and HCG beta-subunits are identical in $82 \%$ of their amino acid sequence, ${ }^{62}$ which will allow HCG to act on LH receptors. The HCG beta-subunit genes appear to have evolved from an ancestral LH beta-subunit gene by multiple gene duplication and rearrangements. ${ }^{62}$

With the introduction of recombinant LH (lutropin alpha) to the market, a preparation with a defined LH activity became available for clinical use.

Luveris $^{\circledR}$ (lutropin- $\alpha$; Serono SA), under extensive testing since 1993, has been first registered in the European Union in 2001.

The drug is characterized by a consistent isoform profile with a high reproducible reliability. ${ }^{63}$ The fundamental advantage in the recombinant production of a gonadotropin is the highly and unreached purification, without any danger of contaminating the probe. In comparison to urine-derived $\mathrm{LH}$ with 60 to $250 \mathrm{IU} \mathrm{LH} / \mathrm{mg}$ protein, the recombinant $\mathrm{LH}$ preparation contains 20,000 to $30,000 \mathrm{IU} \mathrm{LH} / \mathrm{mg}$ protein. ${ }^{64}$

Along with the recombination of the isolated $\alpha$ - and $\beta$-subunits of the hormones, the whole process generates a highly sophisticated product with literally identical properties compared with the native hormone.

Recombinant LH was first studied in nonhuman primates. ${ }^{64}$ The pharmacokinetic trial, designed to compare and reveal possibly differences between pituitary, urine and recombinant $\mathrm{LH}$ and to ascertain the pharmacological properties, showed similar results for mean concentration time curves, mean clearance rates and half-life.

\section{Gonadotropic treatment in $\mathrm{HH}$ women}

$\mathrm{HH}$ describes a condition of very low or undetectable gonadotropins and subsequently arrested follicular growth with low estradiol levels, no ovulation and no menstrual bleeding. The accompanying infertility is the reason for the application of GnRH or gonadotropins to induce follicular growth and restore a normal chance to the patient to get pregnant. The majority of $\mathrm{HH}$ patient are scheduled for ovulation induction after monofollicular growth.

\section{Pulsatile GnRH stimulation}

Due to the most common cause of $\mathrm{HH}$, the pulsatile $\mathrm{GnRH}$ treatment provides a suitable and effective strategy to restore a normal ovarian function. ${ }^{65}$ This therapy induces monofollicular development with physiological estradiol levels and subsequent luteal phase characteristics comparable to a complete normal ovarian function. The pulsatile GnRH treatment showed results slightly superior to HMG stimulation for cumulative pregnancy rate. ${ }^{15}$ Unfortunately, many patients displayed psychological problems and were irritated by the carrying of an electronic pump on their body for several days or weeks.

\section{Gonadotropins (HMG, FSH, LH)}

Daily injections of gonadotropins have been established as a more feasible and tolerated alternative for ovulation induction, with comparable results. ${ }^{66}$ This therapy can be administered by intramuscular or subcutaneous injections of FSH alone or in combination with LH as urinary-derived HMG or more recently as a combination of recombinant FSH and LH. In contrast to the pulsatory GnRH therapy, one of the inherent dangers of this mainly non-physiological stimulation is an ovarian hyper-response with multiple follicular growth, 
followed by an ovarian hyperstimulation syndrome ${ }^{67}$ and a higher risk of multiple pregnancies. ${ }^{15}$ In the normal menstrual cycle, FSH declines and LH rises during the follicular phase. FSH dominates the first half of the follicular phase and LH the second half, with the appearance of LH receptors on granulosa cells. ${ }^{33}$ The normal follicular phase starts with high FSH and low LH levels. Alongside the follicular growth FSH decreases and LH climbs continuously. HMG, with a fixed LH-FSH ratio, represents an non-physiological stimulation, because of the inability to adjust different LH-FSH ratios during the stimulation.

With the introduction of highly purified FSH and, later, recombinant $\mathrm{FSH}$, gonadotropic stimulation became $\mathrm{FSH}$ dominated over the whole period, which is also completely different from the normal cycle.

Very early with the FSH-only stimulation strategy, the necessity of LH in $\mathrm{HH}$ women to achieve a normal follicular growth and oocyte maturation was questioned. ${ }^{53,68-73}$ These first studies demonstrated clearly that stimulation of ovulation induction with FSH alone in LH-depleted women leads to a much higher consumption of the gonadotropin combined with reduced follicular growth, dramatically lower estradiol levels and overall ovulation rates. These non-IVF studies left the unsolved question of whether or not the fertilization competence of the oocyte will be compromised. An IVF treatment in a $\mathrm{HH}$ woman, using a higher FSH dosage than normally given in ovulation induction cycles, showed clearly that an LH-free stimulation induces normal follicular growth with accompanying low estradiol level and without normal oocyte maturation and fertilization competence. ${ }^{74}$ The poor oocyte quality results directly from the insufficient LH secretion and is not caused by a low estradiol level. ${ }^{74}$ The oocyte requires both gonadotropins to achieve full maturation, ${ }^{75}$ but to what extent is not known. ${ }^{76}$

The second question on this topic is the influence of low estradiol level on the pregnancy rate. ${ }^{36}$ Animal studies had shown a clear dependency of the maturing process of the oocyte on normal estradiol levels. ${ }^{77,78}$ In humans, estradiol does not seem to be mandatory for the fertilization competence of the oocyte, ${ }^{74,79,80}$ but it is highly essential for pregnancy rate. ${ }^{81}$ Therefore, estradiol plays a key role in the normal development of the endometrium to achieve full receptivity to the embryo.

\section{Gonadotropin stimulation in IVF patients as a LH depleted model}

While FSH secretion could recognized as mandatory for normal follicular growth, ${ }^{38,53}$ some concerns were raised about the possibly of the deleterious influence of LH on oocyte fertilization rate and pregnancy outcome. ${ }^{82,83} \mathrm{High} \mathrm{LH}$ levels are known to be associated with a premature resumption of meiosis in exposed oocytes ${ }^{84}$ and an inhibition of the granulosa cell proliferation. ${ }^{50}$ Additionally, with reports of higher pregnancy rates in downregulated IVF patients using FSH compared with $\mathrm{HMG},{ }^{85}$ the gain from LH became questionable. These observations have led to a concept of a $\mathrm{LH}$ "ceiling" level, beyond which normal follicular growth and oocyte quality will be compromised by $\mathrm{LH}^{86}$

Through the very low incidence of $\mathrm{HH}$, many studies on the influence of LH on follicular growth and oocyte quality embraced downregulated patients undergoing an IVF procedure. The downregulation with GnRH analogs results in very low gonadotropin levels. Despite some very distinct differences between the controlled ovarian hyperstimulation in IVF and the monofollicular stimulation in $\mathrm{HH}$ women, only the IVF procedure provides the opportunity to verify the influence of the different gonadotropin preparations on stimulation success like oocyte maturation, fertilization competence and pregnancy rate.

Multiple studies have been done to prove the superiority of a distinct gonadotropin preparation, with very conflicting results. ${ }^{85,87-92}$ These differences can be traced back, at least partly, to the incomplete downregulation through the GnRH agonists or antagonists, where secretion of LH continues to be detectable ${ }^{93,94}$ in varing amounts. ${ }^{95}$ No doubt has been raised about the necessity of a distinct amount of $\mathrm{LH}$ to ensure the resumption of meiosis, ${ }^{96}$ the most crucial process to achieve full chromosomal integrity and oocyte diploidy. ${ }^{97}$ The discussion has focused on the impact of LH on oocyte maturation during the follicular phase. Even in massively downregulated women with LH levels near $1 \mathrm{U} / \mathrm{L}$, no impact of these low LH levels on oocyte quality has been seen ${ }^{98}$ and stimulation with pure FSH did not fail to induce normal follicular growth. ${ }^{99}$ With the introduction of highly purified and, later, recombinant FSH for stimulation in downregulated ( $\mathrm{LH}$ depleted) patients, the need for $\mathrm{LH}$ became uncertain. ${ }^{99}$ Westergaard et al ${ }^{100}$ demonstrated that midfollicular LH levels below $0.5 \mathrm{U} / \mathrm{L}$ do not compromise follicular growth, oocyte fertilization competence or pregnancy rate in downregulated IVF patients. However, this very low $\mathrm{LH}$ action $(<0.5 \mathrm{U} / \mathrm{L})$ during follicular development and oocyte maturation was related to an increased early pregnancy loss, ${ }^{100}$ with an impact on embryonic ploidy. ${ }^{92}$ Can this higher risk of abortion be traced back to an impact of the minimal LH secretion on oocyte/embryo quality? Or a possible lower estradiol increase along the stimulation in 
the low LH group with impact on the endometrium, since in both groups estradiol levels were ample and much higher than in a normal cycle.

A further meta-analysis reported lower ongoing pregnancy rates in women with follicular phase LH levels higher than 1.5 U/L and no impact of low LH levels. ${ }^{101}$ All these studies were done on downregulated patients undergoing an IVF procedure in order to prove the amount of $\mathrm{LH}$ necessary for the achievement of full fertilization competence of the oocyte. The use of the downregulated IVF patient as a model for $\mathrm{HH}$ women contains several limitations because the short-term suppression of LH and FSH in IVF cycles differs from the long lasting and more profound depletion of the gonadotropins in $\mathrm{HH}$ women.

A. Downregulated IVF patients display higher LH levels than $\mathrm{HH}$ women, depending on what GnRH analog was used.

B. Because IVF patients are mainly normally cycling women, the LH depletion period is much shorter than in $\mathrm{HH}$ women.

C. The intraovarian androgenetic milieu, necessary for normal oocyte maturation, ${ }^{34}$ differs completely.

\section{Gonadotropin stimulation for ovulation induction in $\mathrm{HH}$ women}

With the introduction of highly purified $\mathrm{FSH}$ and recombinant FSH, two preparations became available for FSH-only stimulation, even in $\mathrm{HH}$ women. Due to the rare incidence of $\mathrm{HH}$, the first studies embraced just a few participants. In spite of these limitations, these first results showed clearly the necessity of a distinct amount of $\mathrm{LH}$ to achieve full oocyte maturation and ovulation competence. ${ }^{53,68-71,74}$

With respect to the studies discussed above on the influence of different gonadotropin preparations on oocyte quality in downregulated women undergoing an IVF procedure, a threshold level for LH was proposed, necessary for normal follicular development and oocyte maturation. ${ }^{76,102}$ Therefore, with a threshold and "ceiling" level of LH, Shoham postulated the concept of a therapeutic window for LH. ${ }^{102}$

\section{Impact of FSH-only stimulation on cycle quality and follicular maturation}

Stimulation studies with highly purified or recombinant FSH showed a clear correlation between remaining $\mathrm{LH}$ levels and stimulation outcome in $\mathrm{HH}$ women. ${ }^{1,53,70,103}$ Below a LH level of $1 \mathrm{U} / \mathrm{L}, \mathrm{FSH}$ alone was not capable of stimulating follicular growth. ${ }^{104}$ An earlier study by Schoot et $\mathrm{al}^{70}$ clearly demonstrated, however, reduced follicular growth in 4 out of 7 women, all with LH levels below $0.5 \mathrm{U} / \mathrm{L}$.
Shoham et $\mathrm{al}^{73}$ reported on $2 \mathrm{HH}$ women treated with recombinant $\mathrm{FSH}$ that both showed follicular growth with only a small increase in estradiol levels. This agrees with another study by Couzinet et $\mathrm{al}^{53}$ with an ovulation rate of $60 \%$. In that study, women were treated with highly purified $\mathrm{FSH}$, containing $0.09 \% \mathrm{LH}$ bioactivity. In addition to the remaining circulating $\mathrm{LH}$, the low $\mathrm{LH}$ activity was sufficient to sustain complete follicle maturation, since less than $1 \%$ of follicular LH receptors are needed to be stimulated by LH to maintain a proper follicular growth, ${ }^{105}$ in the presence of sufficient FSH. ${ }^{53}$

All these studies showed clearly that a FSH-only stimulation posseses limited value because of an insufficient follicular growth s3,70,104,106 and oocyte maturation $^{74}$ with an increased number of midsized follicles ${ }^{48}$ and very low estradiol levels, ${ }^{69,70,73,104}$ and a subsequent low endometrial score. ${ }^{1,71}$ A clear correlation can be found apparently between the degree of LH depletion and the higher amount of FSH ampoules needed for the stimulation. ${ }^{103}$

\section{$\mathrm{LH}$ and $\mathrm{FSH}$ stimulation in $\mathrm{HH}$ women}

Since there is no doubt about a FSH threshold level, an equally minimum LH level necessary for normal follicular growth in IVF and $\mathrm{HH}$ patients was debated. Although the discussion has been limited to the comparison between downregulated IVF patient and $\mathrm{HH}$ women, the attempts to improve pregnancy rates still focus on the effect of endogenous and exogenous LH.

The first studies in ovulation induction dealing with this topic utilized $\mathrm{HMG}^{15,53,68,71}$ or $\mathrm{HCG}^{107}$ as the only source of LH then available. These first studies showed the dependency of the maturing follicle on LH and FSH. As mentioned above, HMG has a fixed LH/FSH ratio without the chance to adjust the amount of LH and FSH for the stimulation protocol. With the introduction of recombinant FSH and LH, the possibility of an individually adjusted dosage and tailored LH/FSH ratio became available. Several studies have been conducted to prove the benefit of an LH and FSH combined stimulation in $\mathrm{HH}$ women ${ }^{48,103,104,106,108}$ and the value of the LH threshold level. ${ }^{102}$

These studies provide results of high clinical relevance and will be discussed to briefly.

1. The European Recombinant Human LH Study Group first published their data in 1998. ${ }^{104}$ Thirty-eight women with $\mathrm{HH}$ were enrolled in the study and randomized into 4 LH treatment groups (Table 1.)

All groups received a fixed FSH stimulation dose of 150 units (U) daily. In the placebo and the $25 \mathrm{U} \mathrm{LH}$ 
Table I Treatment and stimulation outcome ${ }^{104}$

\begin{tabular}{llll}
\hline No. patients & $\begin{array}{l}\text { LH dosage } \\
\text { (Units) }\end{array}$ & $\begin{array}{l}\text { Ovulation } \\
\text { induction (\%) }\end{array}$ & $\begin{array}{l}\text { Estradiol } \\
\text { (pmol/L) }\end{array}$ \\
\hline 8 & 0 & $0 *$ & 60 \\
7 & 25 & $33^{*}$ & 89 \\
9 & 75 & $80^{*}$ & 855 \\
10 & 225 & $100 *$ & 1598 \\
\hline
\end{tabular}

$*_{p}=0.01$.

group, stimulation failed to induce sufficient follicular growth, with poor ovulation rates, and no pregnancy could be achieved. In the 75 and $225 \mathrm{U}$ LH group, $80 \%$ to $100 \%$ received HCG to trigger ovulation, and 3 pregnancies were reported. Comparing the 75 and $225 \mathrm{U}$ groups, stimulation with $225 \mathrm{U}$ LH showed higher estradiol levels with a lower follicle count. This "ceiling" effect of LH will be discussed later. This was the first study that investigated intensively the influence of LH supplementation on FSH stimulation in $\mathrm{HH}$ women.

2. Shoham et $\mathrm{al}^{106}$ reported on a study, including 39 patients, to compare FSH-only stimulation with a combined FSH/LH stimulation, both with a fixed FSH dosage of $150 \mathrm{U}$ daily. The LH group showed a much higher success in follicular growth than the FSH-only group (Table 2.)

Both studies demonstrated an impressive enhancement of follicular growth through LH supplementation.

Burgues et al, ${ }^{103}$ Kaufmann et $\mathrm{al}^{1}$ and O'Dea et al ${ }^{108}$ investigated the ability of LH/FSH combined stimulation to adjust gonadotropin dosage. All studies reported on comparable results of follicular growth (74\%-87\%), with a clinical pregnancy rate of $22 \%$ per HCG given cycle and a cumulative pregnancy rate (up to 3 cycles) of $74 \%$.

The overall results from these studies demonstrate a clear benefit of $\mathrm{LH}$ in the stimulation of $\mathrm{HH}$ women. Besides a reduction in FSH ampoules needed, ${ }^{103}$ all investigators reported on high rates of normal follicular growth, from $66 \%$ to $87 \% .^{1,103,106,108}$ Through the action of $\mathrm{LH}$ and even in the presence of high FSH stimulation, a trend

Table 2 Treatment and stimulation outcome ${ }^{106}$

\begin{tabular}{llll}
\hline No. patients & $\begin{array}{l}\text { LH dosage } \\
\text { (Units) }\end{array}$ & $\begin{array}{l}\text { Follicular } \\
\text { growth (\%) }\end{array}$ & $\begin{array}{l}\text { Estradiol } \\
\text { (pmol/L) }\end{array}$ \\
\hline 13 & 0 & $2(15,4 \%)^{*}$ & 370 \\
26 & 75 & $17(65.4 \%)^{*}$ & 1240 \\
${ }^{*} p=0.006$. & & &
\end{tabular}

toward fewer midsized follicles or a less severe ovarian over-response could be observed, ${ }^{1,48}$ and subsequently a lower risk of an ovarian hyperstimulation syndrome and/or multiple pregnancies. ${ }^{67}$ Ovulation rates reached were also very high (up to 90\%). ${ }^{103,104}$ Compared with a FSH-only stimulation, the addition of LH led to higher preovulatory estradiol levels ${ }^{48,104}$ and a better endometrium score. ${ }^{106}$ The mid-luteal progesterone levels were found to be two-fold higher in the FSH/LH group than in the FSH-only group. ${ }^{1}$ Pregnancy rates per cycle reached $22 \%{ }^{103}$ and $29 \%,{ }^{104}$ and a cumulative pregnancy rate of $74 \%$ over a maximum of 3 treatment cycles was achieved. ${ }^{108}$

These study results gave interesting insights into the mechanisms of proper follicular growth and the minimum (and maximum) amounts of LH and FSH needed to ensure a normal follicular growth.

The studies with $\mathrm{HH}$ women showed a clear dependency of normal follicular growth on a distinct amount of $\mathrm{LH}$, the LH threshold level. ${ }^{102}$ The value of this threshold level was calculated with $1.2 \mathrm{U} / \mathrm{L}^{106}$ and rejected. ${ }^{104}$ Due to the limitations of the measurement of a hormone and particularly near the lower detection level, these different points of view reflect partly the difficulties of comparing hormone levels from different laboratories with different methods. Therefore, the measurement of circulating immunoreactive LH has only limited value to detect a LH-insufficient patient. ${ }^{81,103,105}$ From a more practical viewpoint, Burgues et al ${ }^{103}$ recommended a stimulation with $75 \mathrm{U}$ LH daily in $\mathrm{HH}$ women with basal LH levels above $1 \mathrm{U} / \mathrm{L}$ and a higher LH dosage in women with more profound LH depletion. On the other hand, another group reported on a sufficient stimulation with $75 \mathrm{U}$ of LH daily in $\mathrm{HH}$ women with $\mathrm{LH}$ levels below $1 \mathrm{U} / \mathrm{L}$, and these $\mathrm{LH}$ levels did not rise during stimulation. ${ }^{104}$ Both groups utilized $150 \mathrm{U}$ FSH for daily injection. The debate on the LH threshold level will go further with the publication of new studies. Until now, the great value of substituting stimulation with $\mathrm{LH}$ for FSH in $\mathrm{HH}$ women has been clearly described and should become established in normal practice.

All those studies showed convincingly that FSH stimulation supplemented with recombinant $\mathrm{LH}$ is superior to FSH-only stimulation in $\mathrm{HH}$ women.

With the availability of recombinant $\mathrm{LH}$, another LHrelated concept could be proved: the LH "ceiling" effect. ${ }^{86}$ And, in fact, an increasing LH dosage will be able to minimize or stop the additional development of midsized follicles and reduce or avoid multiple ovulations. ${ }^{48,104}$ With the occurrence of LH receptors on granulosa cells, LH-only 
stimulation will be able to sustain follicular growth, but only at high levels. ${ }^{47,48}$

The LH "ceiling" concept could be an interesting alternative in case of unwanted multiple follicular growths. The cessation of FSH stimulation and a high LH dosage enables a reduction in follicle count, and could avoid or even limit multiple ovulations and therefore minimize the risk of an ovarian hyperstimulation syndrome and/or multiple pregnancies. ${ }^{67}$

\section{Disclosure}

The authors report no conflicts of interest.

\section{References}

1. Kaufmann R, Dunn R, Vaughn T, et al. Recombinant human luteinizing hormone, lutropin alfa, for the induction of follicular development and pregnancy in profoundly gonadotrophin-deficient women. Clin Endocrinol. 2007;67(4):563-569.

2. Reame NE, Sauder ED, Case GD, Kelch RP, Marshall JC. Pulsatile gonadotropin secretion in women with hypothalamic amenorrhea: evidence that reduced frequency of gonadotropin releasing hormone secretion is the mechanism of persistant anovulation. J Clin Endocrinol Metab. 1985;61(5):851-858.

3. Layman LC. The molecular basis of human hypogonadotropic hypogonadism. Mol Gen Metab. 1999;68(2):191-199.

4. Meysing AU, Kanasaki H, Bedecarrats GY, et al. GNRHR mutations in a woman with idiopathic hypogonadotropic hypogonadism highlight the differential sensitivity of luteinizing hormone and follicle-stimulating hormone to gonadotropin-releasing hormone. J Clin Endocrinol Metab. 2004;89(7):3189-3198.

5. Warren MP. Evaluation of secondary amenorrhea. J Clin Endocrinol Metab. 1996;81(2):437-442.

6. Halasz B, Kiss J, Molnar J. Regulation of the gonadotropin-releasing hormone $(\mathrm{GnRH})$ neuronal system: morphological aspects. J Steroid Biochem. 1989;33(4):663-668.

7. Kessel B, Dahl KD, Kazer RR, et al. The dependency of bioactive follicle-stimulating hormone secretion on gonadotropin-releasing hormone in hypogonadal and cycling women. $J$ Clin Endocrinol Metab. 1988;66(2):361-366.

8. Santen RJ, Manni A, Harvey H. Gonadotropin releasing hormone $(\mathrm{GnRH})$ analogs for the treatment of breast and prostatic carcinoma. Breast Cancer Res Treat. 1986;7(3):129-145.

9. Hales TG, Sanderson MJ, Charles AC. GABA has excitatory actions on GnRH-secreting immortalized hypothalamic (GT1-7) neurons. Neuroendocrinology. 1994;59(3):297-308.

10. Bommer M, Nikolarakis K, Noble EP, Herz A. In vivo modulation of rat hypothalamic opioid peptide content by intracerebroventricular injection of guanidinoethylmercaptosuccinic acid (GEMSA): possible physiological role of enkephalin convertase. Brain Res. 1989; 492(1-2):305-313.

11. Thind KK, Boggan JE, Goldsmith PC. Neuropeptide Y system of the female monkey hypothalamus: retrograde tracing and immunostaining. Neuroendocrinology. 1993;57(2):289-298.

12. Grafstein-Dunn E, Clifton DK, Steiner RA. Regulation of galanin and gonadotropin-releasing hormone gene expression in the hypothalamus and basal forebrain of the rat. Horm Behav. 1994;28(4): $417-423$.

13. Nishihara M, Hiruma H, Kimura F. Interactions between the noradrenergic and opioid peptidergic systems in controlling the electrical activity of luteinizing hormone-releasing hormone pulse generator in ovariectomized rats. Neuroendocrinology. 1991;54(4):321-326.
14. Marshall JC, Eagleson CA, McCartney CR. Hypothalamic dysfunction. Mol Cell Endocrinol. 2002;186(2):227-230.

15. Martin KA, Hall JE, Adams JM, Cowley, Jr WF. Comparison of exogenous gonadotropins and pulsatile gonadotropin-releasing hormone for induction of ovulation in hypogonadotropic amenorrhea. J Clin Endocrinol Metab. 1993;77(1):125-129.

16. Liu JH. Hypothalamic amenorrhea: clinical perspectives, pathophysiology, and management. Am J Obstet Gynecol. 1990;163(5): 1732-1736.

17. Gompel A, Mauvais-Jarvis P. Induction of ovulation with pulsatile GnRH in hypothalamic amenorrhoea. Hum Reprod. 1988;3(4): 473-477.

18. McGee EA, Hsueh AJW. Initial and cyclic recruitment of ovarian follicles. Endocr Rev. 2000;21(2):200-214.

19. Oktay K, Briggs D, Gosden RG. Ontogeny of follicle-stimulating hormone receptor gene expression in isolated human ovarian follicles. J Clin Endocrinol Metab. 1997;82(11):3748-3751.

20. Goldenberg RL, Powell RD, Rosen SW, et al. Ovarian morphology in women with anosmia and hypogonadotropic hypogonadism. Am J Obstet Gynecol. 1976;126(1):91-94.

21. Barnes RB, Namnoum AB, Rosenfield RL, Layman LC. The role of LH and FSH in ovarian androgen secretion and ovarian follicular development: clinical studies in a patient with isolated FSH deficiency and multicystic ovaries. Hum Reprod. 2002;17(1):88-91.

22. McCartney CR, Gingrich MB, Hu Y, Evans WS, Marshall JC. Hypothalamic regulation of cyclic ovulation: evidence that the increase in gonadotropin-releasing hormone pulse frequency during the follicular phase reflects the gradual loss of the restraining effects of progesterone. $J$ of Clin Endocrinol Metab. 2002;87(5): 2194-2200.

23. Fowler PA, Templeton A, Messinis IE. The ovarian modulation of gonadotrophin releasing hormone-induced luteinizing hormone secretion in women. Hum Reprod. 1993;8 Suppl 2:S112-S116.

24. Hall JE, Schoenfeld DA, Martin KA, et al. Hypothalamic gonadotropinreleasing hormone secretion and follicle-stimulating hormone dynamics during the luteal-follicular transition. J Clin Endocrinol Metab. 1992; 74(3):600-607.

25. Stouffer RL, Woodruff TK, Dahl KD, Hess DL, Mather JP, Molskness TA. Human recombinant activin-a alters pituitary luteinizing hormone and follicle-stimulating hormone secretion, follicular development, and steroidogenesis, during the menstrual cycle in Rhesus monkeys. J Clin Endocrinol Metab. 1993;77(1):241-248.

26. Macklon NS, Stouffer RL, Giudice LC, Fauser BCJM. The science behind 25 years of ovarian stimulation for in vitro fertilization. Endocr Rev. 2006;27(2):170-207.

27. Ryan KJ, Petro Z, Kaiser J. Steroid formation by isolated and recombined ovarian granulosa and tehcal cells. J Clin Endocrinol Metab. 1968;28(3):355-358.

28. Hillier SG. Gonadotropic control of ovarian follicular growth and development. Mol Cell Endocrinol. 2001;179(1-2):39-46.

29. Filicori M, Santoro N, Merriam GR, Crowley WF Jr. Characterization of the physiological pattern of episodic gonadotropin secretion throughout the human menstrual cycle. J Clin Endocrinol Metab. 1986;62(6):1136-1144.

30. Hsieh M, Lee D, Panigone S, Horner K, et al. Luteinizing hormonedependent activation of the epidermal growth factor network is essential for ovulation. Mol Cell Biol. 2007;27(5):1914-1924.

31. Bergendah M, Veldhuis JD. Is there a physiological role for gonadotrophin oligosaccharide heterogeneity in humans?III. Luteinizing hormone heterogeneity: a medical physiologist's perspective. Hum Reprod. 2001;16(6):1058-1064.

32. Louvet JP, Harman SM, Schrieber JR, Ross GT. Evidence of a role of adrogens in follicular maturation. Endocrinology. 1975;97(2): 366-372.

33. Filicori M, Cognigni GE. Roles and novel regimens of luteinizing hormone and follicle-stimulating hormone in ovulation induction. J Clin Endocrinol Metab. 2001;86(4):1437-1441. 
34. Lossl K, Andersen AN, Loft A, et al. Androgen priming using aromatase inhibitor and hCG during early-follicular-phase GnRH antagonist down-regulation in modified antagonist protocols. Hum Reprodu. 2006;21(10):2593-2600.

35. Padmanabhan V, Lang LL, Sonstein J, Kelch RP, Beitins IZ. Modulation of serum follicle-stimulating hormone bioactivity and isoform distribution by estrogenic steroids in normal women and in gonadal dysgenesis. J Clin Endocrinol Metab. 1988;67(3):465-473.

36. Fauser BCJM, van Heusden AM. Manipulation of human ovarian function: physiological concepts and clinical consequences. 1997; Endocr Rev. 1997;18(1):71-106.

37. Van Santbrink EJP, van Dessel HJHM, Hop WC, De Jong FH, Fauser BCJM. Decremental follicle-stimulating hormone and dominant follicle development during the normal menstrual cycle. Fertil Steril. 1995;64(1):37-43.

38. Hillier SG. Current concepts of the roles of follicle stimulating hormone and luteinizing hormone in folliculogenesis. Hum Reprod. 1994;9(2): 188-191.

39. Filicori M, Cognigni GE, Taraborrelli S, et al. Luteinizing hormone activity supplementation enhances follicle-stimulating hormone efficacy and improves ovulation induction outcome. J Clin Endocrinol Metab. 1999;84(8):2659-2663.

40. Richards JS. Maturation of ovarian follicles: actions and interactions of pituitary and ovarian hormones on follicular cell differentiation. Physiol Rev. 1980;60(1):51-89.

41. Yamoto M, Shima K, Nakano R. Gonadotropin receptors in human ovarian follicles and corpora lutea throughout the menstrual cycle. Horm Res. 1992;37(1):5-11.

42. Zeleznik AJ, Midgley AR Jr, Reichert LE Jr. Granulosa cell maturation in the rat: increased binding of human chorionic gonadotropin following treatment with follicle-stimulating hormone in vivo. Endocrinology. 1974;95(3):818-825

43. Shima K, Kitayama S, Nakano R. Gonadotropin binding sites in human ovarian follicles and corpora lutea during the menstrual cycle. Obstet Gynecol. 1987;69(5):800-806.

44. Rani CS, Salhanick AR, Armstrong DT. Follicle-stimulating hormone induction of luteinizing hormone receptor in cultured rat granulosa cells: an examination of the need for steroids in the induction process. Endocrinology. 1981;108(4):1379-1385.

45. Groome NP, Illingworth PJ, O’Brien M, Pai R, Rodger FE, Mather JP, McNeilly AS. Measurement of dimeric inhibin B throughout the human menstrual cycle. J Clin Endocrinol Metab. 1996;81(4): 1401-1405.

46. Zeleznik AJ, Hillier SG. The role of gonadotropins in the selection of the preovulatory follicle. Clin Obstet Gynaecol. 1984;27(4): 927-940.

47. Sullivan MW, ANN Stewart-Akers A, Krasnow JS, Berga SL, Zeleznik AJ. Ovarian responses in women to recombinant folliclestimulating hormone and luteinizing hormone ( $\mathrm{LH})$ : A role for $\mathrm{LH}$ in the final stages of follicular maturation. J Clin Endocrinol Metab. 1999;84(1):228-232.

48. Loumaye E, Engrand P, Shoham Z, Hillier SG, Baird DT. Clinical evidence for an LH 'ceiling' effect induced by administration of recombinant human $\mathrm{LH}$ during the late follicular phase of stimulated cycles in World Health Organization type I and type II anovulation. Hum Reprod. 2003;18(2)314-322.

49. Zeleznik AJ, Kubik CJ. Ovarian responses in macaques to pulsatile infusion of follicle- stimulating hormone (FSH) and luteinizing hormone: increased sensitivity of the maturing follicle to FSH. Endocrinology. 1986;119(5):2025-2032.

50. Yong EL, Baird DT, Yates R, Reichert LE Jr, Hillier SG. Hormonal regulation of the growth and steroidogenic function of human granulosa cells. J Clin Endocrinol Metab. 1992;74(4):842-849.

51. Hugues JN, Soussis J, Calderon I. Does the addition of recombinant LH in WHO group II anovulatory women over-responding to FSH treatment reduce the number of developing follicles? A dose-finding study. Hum Reprod. 2005;20(3):629-635.
52. Filicori M, Cognigni GE, Taraborrelli S, et al. Stimulation and growth of antral ovarian follicles by selective $1 \mathrm{~h}$ activity administration in women. J Clin Endocrinol Metab. 2002;87(3):1156 -1161.

53. Couzinet B, Lestrat N, Brailly S, Forest M, Schaison G. Stimulation of ovarian follicular maturation with pure follicle-stimulating hormone in women with gonadotropin deficiency. J Clin Endocrinol Metab. 1988;66(3):552-556.

54. Campbell BK, Dobson H, Baird DT, Scaramuzzi RJ. Examination of the relative role of FSH and $\mathrm{LH}$ in the mechanism of ovulatory follicle selection in sheep. J Reprod Fertil. 1999;117(2):355-367.

55. Sasson R, Rimon E, Dantes A, et al. Gonadotrophin-induced gene regulation in human granulosa cells obtained from IVF patients. Modulation of steroidogenic genes, cytoskeletal genes and genes coding for apoptotic signalling and protein kinases. Mol Hum Reprod. 2004; 10(5):299-311.

56. Lobb DK, Soliman SR, Daya S, Younglai EV. Steroidogenesis in luteinized granulosa cell cultures varies with follicular priming regimen. Hum Reprod. 1998;13(8):2064-2067.

57. Young J, Couzinet B, Chanson P, Brailly S, Loumaye E, Schaison G. Effects of human recombinant luteinizing hormone and folliclestimulating hormone in patients with acquired hypogonadotropic hypogonadism: study of sertoli and leydig cell secretions and interactions. J Clin Endocrinol Metab. 2000;85(9):3239-3244.

58. Pierce JG, Parsons TF. Glycoprotein hormones: structure and function. Annu Rev Biochem. 1981;50:465-495.

59. Gharib SD, Wierman ME, Shupnik MA, et al. Molecular biology of the pituitary gonadotropins. Endocr Rev. 1990;11(1):177-199.

60. Ulloa-Aquirre A, Espinoza R, Damian-Matsumura P, Chappel SC. Immunological and biological potencies of different molecular species of gonadotrophins. Hum Reprod. 1988;3(4):491-501.

61. Filicori M, Cognigni GE, Taraborrelli S, et al. Luteinzing hormone activity in menotropins optimizes folliculogenesis and treatment in controlled ovarian stimulation. J Clin Endocrinol Metab. 2001;86(1): $337-343$.

62. Talmadge K, Vamvakopoulos NC, Fiddes JC. Evolution of the genes for the beta subunits of human chorionic gonadotropin and luteinizing hormone. Nature. 1984;307(5946):37-40.

63. Baer G, Loumaye E. Comparison of recombinant human luteinising hormone (r-hLH) and human menopausal gonadotropin (hMG) in assisted reproductive technology. Curr Med Res Opin. 2003;19(2): 83-88.

64. Porchet H, Le Cotonnec JY, Neuteboom B, Canali S, Zanolo G. Pharmacokinetics of recombinant human luteinizing hormone after intravenous, intramuscular, and subcutaneous administration in monkeys and comparison with intravenous administration of pituitary human luteinizing hormone. J Clin Endocrinol Metab. 1995;80(2): $667-673$.

65. Crowley Jr. WF, McArthur JW. Simulation of the normal menstrual cycle in Kallman's syndrome by pulsatile administration of luteinizing hormone-releasing hormone (LHRH). J Clin Endocrinol Metab. 1980;51(1):173-175.

66. Balen AH, Braat DDM, West C, Patel A, Jacobs HS. Cumulative conception and live birth rates after the treatment of anovulatory infertility: safety and efficacy of ovulation induction in 200 patients. Hum Reprod. 1994;9(8):1563-1570.

67. Navot D, Relou A, Birkenfeld A, Rabinowitz R, Brzezinski A, Margalioth EJ. Risk factors and prognostic variables in the ovarian hyperstimulation syndrome. Am J Obstet Gynecol. 1988;159(1):210-215.

68. Berger MJ, Taymor ML. The role of luteinizing hormone in human follicular maturation and function. Am J Obstet Gynecol. 1971;111(5): 708-710.

69. Fox R, Ekeroma A, Wardle P. Ovarian response to purified FSH in infertile women with long-standing hypogonadotrophic hypogonadism. Aust N Z J Obstet Gynaecol. 1997;37(1):92-94.

70. Schoot DC, Harlin J, Shoham Z, et al. Recombinant human folliclestimulating hormone and ovarian response in gonadotrophin-deficient women. Hum Reprod. 1994;9(7):1237-1242. 
71. Shoham Z, Balen A, Patel A, Jacobs HS. Results of ovulation induction using human menopausal gonadotropin or purified follicle-stimulating hormone in hypogonadotropic hypogonadism patients. Fertil Steril. 1991;56(6):1048-1053.

72. Schoot DC, Coelingh Bennink HJ, Mannaerts BM, Lamberts SW, Bouchard P, Fauser BC. Human recombinant follicle-stimulating hormone induces growth of preovulatory follicles without concomitant increase in androgen and estrogen biosynthesis in a woman with isolated gonadotropin deficiency. J Clin Endocrinol Metab. 1992;74(6): 1471-1473.

73. Shoham Z, Mannaerts B, Insler V, Coelingh-Bennink H. Induction of follicular growth using recombinant human follicle-stimulating hormone in two volunteer women with hypogonadotropic hypogonadism. Fertil Steril. 1993;59(4):738-742.

74. Balasch J, Miró F, Burzaco I, et al. The role of luteinizing hormone in human follicle development and oocyte fertility: evidence from in-vitro fertilization in a woman with long-standing hypogonadotrophic hypogonadism and using recombinant human follicle stimulating hormone. Hum Reprod. 1995;10(7):1678-1683.

75. Glasier AF, Wickings EJ, Hillier SG, et al. Both LH and FSH are required for the development of the normal follicle. J Endocrinol. 1988; 119(Suppl):A-159.

76. Huirne JAF, van Loenen ACD, Schats R, et al. Dose-finding study of daily GnRH antagonist forthe prevention of premature LH surges in IVF/ICSIpatients: optimal changes in LH and progesteronefor clinical pregnancy. Hum Reprod. 2005;20(2):359-367.

77. Hsueh AJ, Adashi EY, Jones PB, et al. Hormonal regulation of the differentiation of cultured ovarian granulosa cells. Endocr Rev. 1984;5(1):76-127.

78. Murray AA, Swales AKE, Smith RE, Molinek MD, Hillier SG, Spears N. Follicular growth and oocyte competence in the in vitro cultured mouse follicle: effects of gonadotrophins and steroids. Mol Hum Reprod. 2008;14(2):75-83.

79. Balasch J. The potential value of mid-follicular phase LH. Hum Reprod. 2002;17(2):517-523.

80. Rabinovici J, Blankstein J, Goldman B, et al. In vitro fertilization and primary embryonic cleavage are possible in 17 alpha-hydroxylase deficiency despite extremely low intrafollicular 17 beta-estradiol. J Clin Endocrinol Metab. 1989;68(3):693-697.

81. Loumaye E, Engrand P, Howles CM, O'Dea L. Assessment of the role of serum luteinizing hormone and estradiol response to folliclestimulating hormone on in vitro fertilization treatment outcome. Fertil Steril. 1997;67(5):889-899.

82. Regan L, Owen EJ, Jacobs HS. Hypersecretion of luteinising hormone, infertility, and miscarriage. Lancet. 1990;336(8724):1141-1144.

83. Watson H, Kiddy DS, Diana Hamilton-Fairley D, et al. Hypersecretion of luteinizing hormone and ovarian steroids in women with recurrent early miscarriage Hum Reprod. 1993;8(6):829-833.

84. Howles CM. Role of LH and FSH in ovarian function. Mol Cell Endocrinol. 2000;161(1-2):25-30.

85. Daya S, Gunby J, Hughes EG, Collins JA, Sagle MA. Folliclestimulating hormone versus human menopausal gonadotropin for in vitro fertilization cycles: a meta-analysis. Fertil Steril. 1995;64(2):347-54.

86. Hillier SG. Ovarian stimulation with recombinant gonadotrophins: LH as adjunct to FSH. In: Jacobs HS, editor. The new frontier in ovulation induction. Carnforth: Parthenon; 1993. p. 39-47.

87. Gordon UD, Harrison RF, Fawzy M, et al. A randomized prospective assessor-blind evaluation of luteinizing hormone dosage and in vitro fertilization outcome. Fertil Steril. 2001;75(2):324-331.

88. Agrawal R, Holmes J, Jacobs HS. Follicle-stimulating hormone or human menopausal gonadotropin for ovarian stimulationin in vitro fertilization cycles: a meta-analysis. Fertil Steril. 2000;73(2):338-343.

89. Check JH, Nazari P, Choe JK, et al. Evaluation of pregnancy and implantation rates following controlled ovarian hyperstimulation $(\mathrm{COH})$ using all follicle stimulating hormone (FSH) versus FSH/luteinizing hormone ( $\mathrm{LH})$ combination according to the serum $\mathrm{LH}$ obtained in the early follicular phase. Fertil Steril. 2000;74(3 Suppl):S228.
90. Ng EHY, Lau EYL, Yeung WSB, Ho PC. HMG is as good as recombinant human $\mathrm{FSH}$ in terms of oocyte and embryo quality: a prospective randomized trial. Hum Reprod. 2001;16(2):319-325.

91. Van Wely M, Westergaard LG, Bossuyt PMM, Van der Veen F. Human menopausal gonadotropin versus recombinant follicle stimulation hormone for ovarian stimulation in assisted reproductive cycles. Cochrane Database Syst Rev. 2003; Issue 1. Art. No.: CD003973. DOI: 10.1002/14651858.CD003973.

92. Weghofer A, Munne S, Brannath W, et al. The impact of LH-containing gonadotropins on diploidy rates in preimplantation embryos: long protocol stimulation Hum Reprod. 2008;23(3):499-503.

93. Loumaye E. The control of endogenous secretion of LH by gonadotrophin-releasing hormone agonists during ovarian hyperstimulation for in-vitro fertilization and embryo transfer. Hum Reprod. 1990;5(4):357-376.

94. Sills ES, Levy DP, Moomjy M, McGee M, Rosenwaks Z. A prospective, randomized comparison of ovulation induction using highly purified follicle-stimulating hormone alone and with recombinant human luteinizing hormone in in-vitro fertilization. Hum Reprod. 1999;14(9): 2230-2235.

95. Balasch J, Vidal E, Peñarrubia J, et al. Suppression of LH during ovarian stimulation: analysing threshold values and effects on ovarian response and the outcome of assisted reproduction in down-regulated women stimulated with recombinant FSH. Hum Reprod. 2001;16(8): $1636-1643$.

96. Hsieh M, Lee D, Panigone S, et al. Luteinizing hormone-dependent activation of the epidermal growth factor network is essential for ovulation. Mol Cell Biol. 2007;27(5):1914-1924.

97. Verlinsky Y, Kuliev A. Preimplantation diagnosis of common andiploidies in infertile couples of advanced maternal age. Hum Reprod. 1996;11(10):2076-2077.

98. Yim SF, Lok IH, Cheung LP, Briton-Jones CM, Chiu TTY, Haines CJ. Dose-finding study for the use of long-acting gonadotrophin-releasing hormone analogues prior to ovarian stimulation for IVF. Hum Reprod. 2001;16(3):492-494.

99. Ben-Chetrit A, Gotlieb L, Wong PY, Casper RF. Ovarian response to recombinant human follicle stimulating hormone in luteinizing hormonedepleted women: examination of the two cell, two gonadotropin theory. Fertil Steril. 1996;65(4):711-717.

100. Westergaard LG, Laursen SB, Andersen CY. Increased risk of early pregnancy loss by profound suppression of luteinizing hormone during ovarian stimulation in normogonadotrophic women undergoing assisted reproduction. Hum Reprod. 2000;15(5):1003-1008.

101. Kolibianakis EM,Collins J, Tarlatzis B, et al. Are endogenous LH levels during ovarian stimulation for IVF using GnRH analogues associated with the probability of ongoing pregnancy? A systematic review. Hum Reprod Update. 2006;12(1):3-12.

102. Shoham $Z$. The clinical therapeutic window for luteinizing hormone in controlled ovarian stimulation. Fertil Steril. 2002;77(6): 1170-1177.

103. Burgues $\mathrm{S}$. The effectiveness and safety of recombinant human $\mathrm{LH}$ to support follicular development induced by recombinant human FSH in WHO group I anovulation: evidence from a multicentre study in Spain. Hum Reprod. 2001;16(12):2525-2532

104. The European Recombinant Human LH Study Group. Recombinant human luteinizing hormone $(\mathrm{LH})$ to support recombinant human follicle-stimulating hormone (FSH)-induced follicular development in LH- and FSH-deficient anovulatory women: A dose- finding study. J Clin Endocrinol Metab. 1998;83(5):1507-1514.

105. Chappel SC, Howles C. Reevaluation of the roles of luteinizing hormone and follicle-stimulating hormone in the ovulatory process. Hum Reprod. 1991;6(9):1206-1212.

106. Shoham Z, Smith H, Yeko T, O’Brien F, Hemsey G, O'Dea L. Recombinant LH (lutropin alfa) for the treatment of hypogonadotrophic women with profound LH deficiency: a randomized, doubleblind, placebo-controlled, proof-of-efficacy study. Clin Endocrinol. 2008;69(3):471-478. 
107. Filicori M, Cognigni GE, Taraborrelli S, Spettoli D, Ciampaglia W, de Fatis CT. Low-dose human chorionic gonadotropin therapy can improve sensitivity to exogenousfollicle-stimulating hormone in patients with secondary amenorrhea. Fertil Steril. 1999;72(6): $1118-1120$.
108. O’Dea L, O’Brien F, Hemsey G, Dunn RC, Kaufmann R, Vaughn T. Flexible dosing of recombinant human follitropin alfa (r-hFSH) optimizes pregnancy rates for profoundly luteinizing hormone (LH)-deficient hypogonadotropic hypogonadal patients treated with recombinant human lutropin alfa (r-hLH). Fertil Steril. 2004;82(2):307.

\section{Publish your work in this journal}

Biologics: Targets \& Therapy is an international, peer-reviewed journal focusing on the patho-physiological rationale for and clinical application of Biologic agents in the management of autoimmune diseases, cancers or other pathologies where a molecular target can be identified. This journal is indexed on PubMed Central, CAS,
Dovepress

EMBase, Scopus and the Elsevier Bibliographic databases. The manuscript management system is completely online and includes a very quick and fair peer-review system, which is all easy to use. Visit http://www.dovepress.com/testimonials.php to read real quotes from published authors. 